\title{
Applications of Metabolities Extracted from Macroalgae to Fight Neglected Diseases in Brazil
}

\author{
João Pedro Santos Alves ${ }^{1 *}$, Cauã de Souza Fariass ${ }^{1}$, Caíque Cardoso dos Santos Silva ${ }^{1}$, Ana Lúcia Barbosa de Souza ${ }^{1}$ \\ ${ }^{I}$ SENAI CIMATEC University Center; Salvador, Bahia, Brazil
}

\begin{abstract}
Microorganisms provoke neglected diseases. However, social factors intensified those affected by them. Macroalgae are photosynthetic beings that live in oceans. They are divided into three categories: green, red, and brown algae. These groups are known for having metabolites with various applications in biotechnology and natural products chemistry. The present work aimed to discuss, through bibliographic review, the applications of substances extracted from macroalgae to the treatment of forgotten diseases in Brazil. This research concludes that literature has studies focused on the presence and absence of these compounds, namely its qualitative aspects, in which pharmacological, pharmacodynamic, and reaction mechanisms fields of these bioactive constituents are described.
\end{abstract}

Keywords: Neglected Diseases. Macroalgae. Metabolites.

\section{Introduction}

Algae are organisms with photosynthetic capacity located in aquatic and continental environments. They provide protection and food resources for fish and invertebrates. They are divided into macroalgae (multicellular individuals) and microalgae (unicellular individuals). Three major taxa are: Rhodophyta, Phaeophyta, and Chlorophyta, also referred to as red, brown, and green algae, respectively $[1,2]$.

Therefore, macroalgae are responsible for a large portion of the worldwide produced algae biomass, opening spaces for research development due to its vast production of metabolites and providing relevance to studies regarding pharmaceutical products used to fight infectious agents. Among the metabolites emphasized in previous studies, the caulerpin, a derivative of the Caulerpa, seaweeds in the family Caulerpaceae and phylum Chlorophyta. This compound has antitumor and antimicrobial activities, as the Spatoglossum schroederi seaweed, a member of the phylum Phaeophyta,

Received on 22 June 2021; revised 27 August 2021.

Address for correspondence: João Pedro Santos Alves. Av. Orlando Gomes, 1845 - Piatã, Salvador - BA- Brazil. Zipcode: 41650-010. E-mail: joaopedrosa2002@gmail.com.

J Bioeng. Tech. Appl. Health 2021;4(3):105-110. (C) 2021 by SENAI CIMATEC. All rights reserved. which has a bioactive compound (fucoidan) with pharmacological activity. Likewise, the phylum Rhodophyta has shown antimalarial activity in literature, these red algae are located in the state of Ceará, reaching the southern limit of the state of Espírito Santo [1,4].

Currently, neglected diseases in Brazil are caused by infectious and parasitic pathogens that endemically affect vulnerable populations in developing countries, which lack positive therapeutic actions such as vaccines and medical diagnosis. These factors can damage communities that already do not have access to health-related resources, preventing them from better assistance and contributing to unequal reality. According to the Fundação Getulio Vargas $(\mathrm{FGV})$, the prediction was that, in February 2021, 27.2 million people in Brazil would be living in poverty, which represents $12.83 \%$ of the Brazilian population. Thus, the growing cases of forgotten diseases in Brazil, such as dengue, Chagas disease, tuberculosis, malaria, cancer, leishmaniasis, and others, are inevitable $[2,3]$.

The present work aims to highlight, through a bibliographic review, the management and application of metabolites from macroalgae to fight neglected diseases in Brazil.

\section{Materials and Methods}

We did literature research using papers published throughout the last 11 years (2010-2021) 
in the following databases: Instituto Nacional da Propriedade Industrial (INPI), Google Scholar, Scientific Electronic Library Online (SciELO), Periódico CAPES, Science Direct, and Espacenet. During the investigation, we searched for the words "seaweed and neglected diseases in Brazil", "green algae", "red algae", "golden algae", "seaweeds and metabolites", as well as "seaweeds and biopharmaceuticals", using the Portuguese, English, and Spanish languages. All studies were selected according to our subject of interest, and the pre-selected materials consisted of articles, doctoral thesis, and thesis.

\section{Results and Discussion}

We gathered 25 scientific materials, including original scientific articles, doctoral theses, masters' dissertations, and patent documents. Due to its continental dimensions, Brazil has a big coastline with potential for finding several species of macroalgae. It facilitates the opportunity of developing new pharmaceutical products for the treatment of neglected diseases and their consequences resulting from the current management methods.

On the other hand, neglected diseases are current for Brazilian citizens, causing a decrease in the well-being in the affected people. In addition, most of the existing drug treatments have demonstrated short-and long-term side effects, such as anticholinergics and opioids used for diarrhea, antimonials employed to treat leishmaniasis, and chemotherapy for various types of cancer $[1,(24,25)]$. Furthermore, several microorganisms acquire chemical resistance, owing to the prolonged use of treatments and indiscriminate lack of medical control for neglected diseases [3].

The unsuccessful therapeutic initiatives mentioned in the literature incentivates the research community to study therapies and medicines derived from natural resources, as well as the use of inputs extracted from macroalgae. The studies present a reduction of side effects and positive actions against such diseases when compared with the traditional one. Such applications are encouraged by the World Health Organization [46].

Dichloromethane and methanol extracts of Dictyota mertensi collected at the Itapuama Beach, Pernambuco-Brazil, exhibited 100\% of leishmanicidal and cytotoxic activities, inhibiting the growth of promastigotes in the form of Leishmania amazonensis in vitro. Inputs from Lobophora variegata, Padina gymnospora, Hypnea musciformis, Ulva fasciata, Ulva lactuca, and Caulerpa prolifera collected from the coast of Ceará, are useful in the inhibition of $S$. aureus and Salmonella with the antibiotic-resistance profile. L. variegata and $H$. musciformis exhibited antimicrobial activity against Vibrio harveyi, which resists six types of industrial drugs, besides being a human and marine zoonotic pathogen.Methanol and ethanol-based raw materials obtained from Padina gymnospora, U. lactuca, and C. prolifera managed to neutralize the dengue virus type 3, an occurrence for the Brazilian health scenario, which seasonally faces outbreaks of dengue and correlated illnesses [7,(20-25)].Spatoglossum schroederi, Udotea flabellum, and Gracilaria birdiae - taken from substrates that originated in the coast of Rio Grande do Norte - showed parasite reduction and antimalarial activity against the Plasmodium falciparum species, expressing advantage compared to chloroquine. Other algae species such as $C$. glomerata, D. dichotoma, S. furcellata S. natans, and $U$. lactuca also have the antispasmodic operation following the action of meroditerpenes, tocopherols, b-tocopheryl-hydroquinone, and d-tocopheryl-hydroquinone. Sesquiterpenes from $L$. dendoidrea, obtained in the herbarium of the Universidade Federal do Rio de Janeiro (URFJ), reacted to leishmaniasis [8]. Fractions of Prasiola crispa contain a high leishmanicidal effect with efficiency, aside from having no toxicity to humans [9]. Inputs acquired 
through solvent extraction using $S$. vulgare, $P$. flagellifera, $U$. fasciata collected on the coast of Bahia, demonstrated the following percentages of HIV inhibition: $89.92 \%, 37.18 \%$, and $35.85 \%$, respectively [10].

The genus Gracilaria has species with antibiotic activity in their extracts analyzed during in vitro studies, which tested their effects on Gram-positive and Gram-negative bacteria, such as Vibrio cholera, Staphylococcus aureus, Shigella dysenteriae, Salmonella paratyphi, and Pseudomonas aeruginosa. Soxhlet extraction using ethanol and methanol on Gracilaria debilis, G. cervicornis, G. corticata, $G$. domigensis, and $G$. debilisi generate inputs employed as antibacterial agents for multidrug-resistant organisms in severe cases of infections. Whereas Gracilaria bursa-pastoris and Gracilaria sp., when in contact with methanol, provide citrullinylarginine (Figure 1), a compound with antiretroviral activity regarding the human immunodeficiency virus (HIV), the herpes simplex virus (HSV), and the human papillomavirus (HPV) [11]. However, the reactions involved in these processes are unknown due to the lack of further research on such compounds, thus highlighting the need to assess the toxicity levels produced by prostaglandins, obtained from the mentioned algae through bioassays [12]. These species are found in Brazil from the coast of Ceará to the state of Espírito Santo [13].

Table 1 shows more applications of chemical inputs obtained from macroalgae in neglected diseases.

\section{Conclusion}

Based on many social problems surrounding neglected diseases in Brazil, the use of chemical compounds extracted from macroalgae to the direct and indirect treatment of pathologies should be well-studied. Besides, these compounds reduce side effects caused by conventional treatments and improve the wellbeing of vulnerable Brazilian populations.

Despite many metabolites discovered in marine and coastal macroalgae, the pharmacological and pharmacodynamic descriptions and the mechanisms of the action are still superficially explored to fight diseases.

So, further studies are needed to elucidate the interaction between these compounds and neglected diseases. Therefore, the scientific usage of the marine environment has to be aligned with the current societal sustainable mentality, highlighting the need to provide investments for studies focused on the mechanisms of action of these compounds.

Figure 1. Structure of citrullinylarginine.

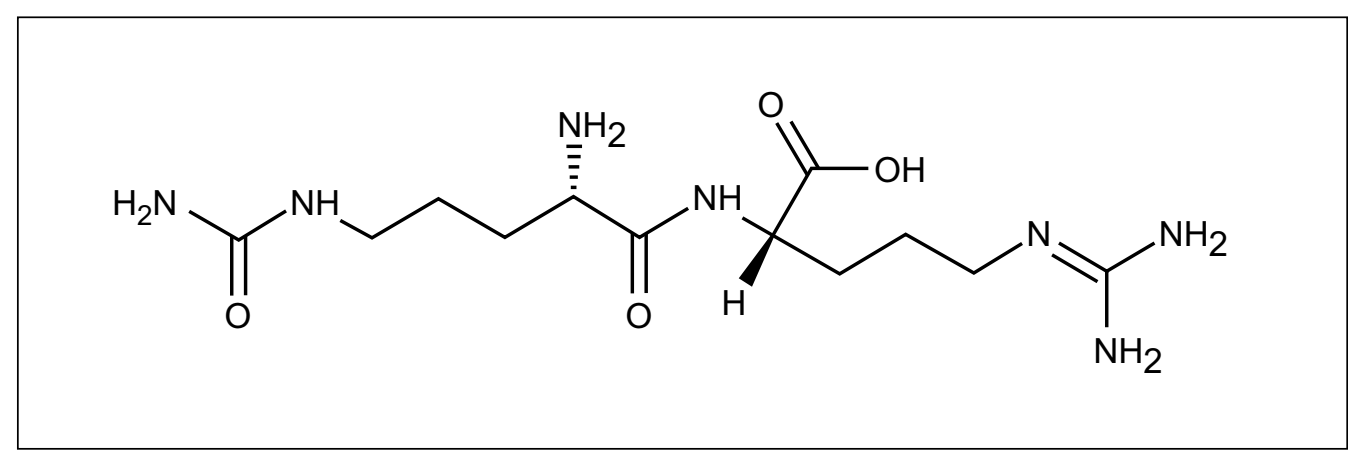


Table 1. Applications of macroalgae chemicals.

\begin{tabular}{|c|c|c|c|}
\hline Species & Substance & Application & References \\
\hline $\begin{array}{l}\text { Octhodea secundiramea } \\
\text { (red seaweed) }\end{array}$ & $\begin{array}{l}\text { Halogenated, monoterpenes } \\
\text { and octodens }\end{array}$ & Schistosomicidal activity & {$[14]$} \\
\hline $\begin{array}{l}\text { Byrothamnion triquetrum, } \\
\text { Gracilaria birdia, and } \\
\text { Gracilaria caudata } \\
\text { (red seaweed) }\end{array}$ & Sulfated polysaccharides & $\begin{array}{l}\text { Antinociceptive action generated by the } \\
\text { treatment of neglected diseases and } \\
\text { reduction of gastrointestinal lesions } \\
\text { caused by antibiotics and acute } \\
\text { antidiarrheal drugs }\end{array}$ & {$[1]$} \\
\hline $\begin{array}{l}\text { Dictyota caribea } \\
\text { (brown seaweed) }\end{array}$ & $\begin{array}{l}\text { Sulfated polysaccharides } \\
\text { (fucoidans), diterpenes, } \\
\text { primarymetabolites }\end{array}$ & $\begin{array}{l}\text { In vitro macrophage activation for } \\
\text { epidermal carcinomas, reduction } \\
\text { of sarcoma } 180\end{array}$ & {$[15]$} \\
\hline $\begin{array}{l}\text { Caulerpa lentillifera } \\
\text { (green seaweed) }\end{array}$ & Fucoidans & $\begin{array}{l}\text { Apoptosis of sarcoma } 180 \text { and increased } \\
\text { production of murine macrophages with } \\
\text { M1 phenotype for antitumor activity }\end{array}$ & {$[15,16]$} \\
\hline $\begin{array}{l}\text { Lobophora variegata } \\
\text { (brown seaweed) }\end{array}$ & $\begin{array}{l}\text { Polyunsaturated henecosanoid } \\
\text { epoxide, apo-13'-fucoxanthinone, } \\
\text { phytanyl glyceryl ether }\end{array}$ & $\begin{array}{l}\text { Cytotoxicity against cancer cells and } \\
\text { decrease in nitrous oxide responsible for } \\
\text { HCT } 116 \text { derived inflammations }\end{array}$ & {$[17]$} \\
\hline $\begin{array}{l}\text { Laurencia intricata, } \\
\text { Laurencia obtusa, } \\
\text { Laurencia microcladia, } \\
\text { Leishmania mexicana, } \\
\text { Laurencia scoparia, Undaria } \\
\text { pinnatifida, and Plocamium } \\
\text { cartilagineum } \\
\text { (red seaweed) }\end{array}$ & $\begin{array}{l}\text { Diterpene, laurediterpineol, } \\
\text { 7-hydroxyllaurane, } \\
\text { bromolaurenisol, sesquiterpene, } \\
\text { elatol, trichomonicide, } \\
\beta \text {-bisabolene, fucoxanthin, } \\
\text { terpenoids, polar fractions } \\
\text { florotannins, sterols, alkaloid, } \\
\text { and bromophenols }\end{array}$ & $\begin{array}{l}\text { Antitumor activity against T47D cell } \\
\text { lines and HIF-1 factors, both related to } \\
\text { breast tumor cells. They are also inhibitors } \\
\text { of K562 cells, epidermal, cervix, and } \\
\text { myelogenous adenocarcinoma derivatives, } \\
\text { lung and prostate tumors. They show a } \\
\text { significant decrease in the action of } \\
\text { helminth parasites and sexually } \\
\text { transmitted infections }\end{array}$ & {$[8,18]$} \\
\hline $\begin{array}{l}\text { Gayralia oxysperma, } \\
\text { Monostroma nitidum, and } \\
\text { Capsosiphon fulvescens } \\
\text { (green seaweed) }\end{array}$ & $\begin{array}{l}\text { Rhamnans, sulfated, manoxylans, } \\
\text { and sulfated heteroramnans }\end{array}$ & $\begin{array}{l}\text { Inhibition of gastric tumor cells, } \\
\text { Vero cells, human glioma, and } \\
\text { herpes activity }\end{array}$ & {$[19]$} \\
\hline $\begin{array}{l}\text { Portieria hornemannii, } \\
\text { Plocamium cornutum, } \\
\text { and Callophycus serratus } \\
\text { (red seaweed) } \\
\text { Udotea orientalis } \\
\text { (green seaweed) }\end{array}$ & $\begin{array}{l}\text { Pentahalogenated terpenes, } \\
\text { oxygenated monoterpenes, } \\
\text { bromoficolides, aromatic } \\
\text { sesquiterpenes, diterpenes, } \\
\text { sulfated polysaccharides, and } \\
\text { C-6 galactose }\end{array}$ & $\begin{array}{l}\text { Inhibition of brain, kidney and, } \\
\text { colon tumor cells. Antiplasmodic } \\
\text { activity against Plasmodium, } \\
\text { antimalarial, aside from anti- } \\
\text { titrypanosomal activity opposed } \\
\text { to Trypanosoma cruzi amastigotes, } \\
\text { antiviral action in vitro against DENV-1, } \\
\text { DENV- 2, DENV-3, and DENV-4 }\end{array}$ & {$[20]$} \\
\hline $\begin{array}{l}\text { Cladophora glomerata, } \\
\text { Ulva prolifera, and } \\
\text { Ulva lactuca } \\
\text { (red seaweed) }\end{array}$ & $\begin{array}{l}\text { Indoleacetic acid, Indolebutyric } \\
\text { acid, kinetin, polysaccharide } \\
\text { extracts, and aqueous extracts }\end{array}$ & $\begin{array}{l}\text { Antioxidant and anti-inflammatory } \\
\text { actions, pancreatic fat breaking, } \\
\text { antibacterial management against } \\
\text { Escherichia coli }\end{array}$ & {$[21-23]$} \\
\hline
\end{tabular}




\section{References}

1. Ribeiro CVPE. Estrutura e atividade antidiarreica de polissacarídeos da alga marinha vermelha Bryothamnion triquetrum Melin SGG. 2016. 80 f. Dissertação (Mestrado) Curso de Programa de Pós- Graduação em Bioquímica, Departamento de Bioquímica e Biologia Molecular, Universidade Federal do Ceará, Fortaleza, 2016.

2. Silva EVD. Estudo toxicológico, atividade antioxidante e antitumoral da macroalga marinha Caulerpa taxifolia (Vahl) Agardh (1817) Caulerpaceae. 2011.70f. Dissertação (Mestrado). Curso de Programa de PósGraduação em Ciências Farmacêuticas, Universidade Federal de Pernambuco, Recife, 2016.

3. Michelleti A, Beatriz A. Progressos recentes na pesquisa de compostos orgânicos com potencial atividade leishmanicida. Revista Virtual de Química, Web 2012;(4)3:1-19.

4. Costa DS, et al. Sulphated polysaccharide isolated from the seaweed Gracilaria caudata exerts an antidiarrhoeal effect in rodents. Basic \& Clinical Pharmacology \& Toxicology, [S.L.] 2016;(118)6:440-448. 2016. Wiley. http://dx.doi.org/10.1111/bcpt.12531.

5. Iwasaki S, et al. In vivo antioxidant activity of fucoxanthin on obese/diabetes KK-Ay mice. Food and Nutrition Sciences [S.L.] 2012;3(11):1491-1499. Scientific Research Publishing, Inc. http://dx.doi. org/10.4236/fns.2012.311194.

6. Aguiar BA, et al. Propriedades antioxidantes de metabólitos secundários de algas pardas: uma revisão integrativa. Produtos Naturais e Suas Aplicações: da Comunidade para o Laboratório. Editora Científica Digital [S.L.] 2021:129-142. http:// dx.doi.org/10.37885/210303827.

7. Silva GC. Extratos bioativos de algas marinhas da costa do Ceará: determinação de atividade contra o vírus da dengue e bactérias patogênicas resistentes a múltiplos antimicrobianos. 2017. $91 \mathrm{f}$. Tese (Doutorado) - Curso de Programa de Pós-Graduação em Ciências Marinhas Tropicais, Instituto de Ciências do Mar, Universidade Federal do Ceará, Fortaleza, 2017.

8. Machado FLDS, et al. Chemical diversity and antileishmanial activity of crude extracts of Laurencia complex (Ceramiales, Rhodophyta) from Brazil. Revista Brasileira de Farmacognosia [S.L. 2014;24(6):635643. Springer Science and Business Media LLC. http:// dx.doi.org/10.1016/j.bjp.2014.10.009.

9. Santos, et al. Composição Farmacêutica com frações derivadas de algas marinhas e seu usocomo agente leishmanicidae Depositante: Uninersidade Federal Fluminense. BR 102019018113-3 A2. Depósito: 30 jan 2019. Concessão: 16 mar 2021.
10. Santos JP. Perfil antioxidante e bioatividade de três espécies de macroalgas da Praia do Morro de Pernambuco no litoral Sul da Bahia, 2016. Tese (Doutorado) - Curso de Programa de Pós-graduação em Botânica, Instituto de Biociências, Universidade de São Paulo, São Paulo, 2016.

11. Cabral ISR, et al. Produtos naturais de algas marinhas e seu potencial antioxidante e antimicrobiano. Boletim do Centro de Pesquisa de Processamento de Alimentos. [S.L.] 2011;29(2):1-12. Universidade Federal do Paraná. http://dx.doi.org/10.5380/cep.v29i2.2548.

12. Almeida CLF, et al. Bioactivities from Marine algae of the genus Gracilaria. International Journal of Molecular Sciences [S.L.] 2011;(12)7:4550-4573. MDPI AG. http://dx.doi.org/10.3390/ijms12074550.

13. Araujo GS, Rodrigues JAG. Maricultura da alga marinha vermelha Gracilaria birdiae em Icapuí, Ceará, Arq. Ciên. Mar, Fortaleza 2011;44(1):62-68.

14. Tessaro JDS. Obtenção de monoterpenos halogenados com atividade cercaricida a partir do extrato da alga marinha Ochtodes secundiramea (Rhodophyta). 2020. 32 f. Monografia (Especialização) - Curso de Especialista em Biotecnologia para a Saúde: Vacinas e Biofármacos, Centro de Formação de Recursos Humanos para O Sus/Sp "Doutor Antônio Guilherme de Souza", Instituto Butantan, São Paulo, 2020.

15. Assef ANB. Meio condicionado de macrófagos ativados por polissacarídeos sulfatados da alga parda Dictyota caribaea inibe a proliferação de melanoma metastático in vitro. 2017. 87 f. Dissertação (Mestrado) - Curso de Programa de Pós-Graduação em Farmacologia, Departamento de Fisiologia e Farmacologia, Universidade Federal do Ceará, Fortaleza, 2017.

16. Vasconcelos AG, Araújo KVD, Santana LDAB. Polissacarídeos estraídos de algas marinhas e suas aplicações biotecnológicas: uma revisão. Revista Brasileira de Inovação Tecnológica em Saúde - Issn: 2236-1103, [S.L.] 2014;5(3):1-17. (red seaweed) http:// dx.doi.org/10.18816/r- bits.v5i3.5898.

17. Ferreira KQ, Loboforenos inéditos obtidos da alga parda Lobophora variegata com atividade citotóxica em células tumorais e moduladora da resposta inflamatória de macrófagos. 2018. $90 \mathrm{f}$. Dissertação (Mestrado) - Curso de Programa de Pós-Graduação em Farmacologia, Departamento de Fisiologia e Farmacologia, Universidade Federal do Ceará, Fortaleza, 2018.

18. Andreguetti DX. Prospecção de bioativos farmacológicos em algas marinhas Rhodophyta e Heterokontophyta e avaliação de citotoxicidade. 2015. 171 f. Tese (Doutorado) - Programa de Pós-Graduação em Toxicologia e Análise de Alimentos, Faculdade de 
Ciências Farmacêuticas, Universidade de São Paulo, 2015.

19. Carvalho MMD. Heteroramnanas sulfatadas obtidas de Gayralia oxysperma: investigação domecanismo de atividade antitumoral e caracterizaçãoquímica dos produtos de degradação parcial. 2013, 144 f. Dissertação (Mestrado) - Curso de Ciências - Bioquímica, Ciências Biológicas, Universidade Federal do Paraná, Curitiba, 2013.

20. Freile-Peledrín Y, Tasdemir D. Seaweeds to the rescue of forgotten diseases: a review. Botanica Marina [S.L.] 2019; 62(3):211-226. Walter de Gruyter GmbH. http:// dx.doi.org/10.1515/bot-2018-0071.

21. Górka B, Wieczorek PP. Simultaneous determination of nine phytohormones in seaweed and algae extracts by HPLC-PDA. Journal of Chromatography 2017;1057:32-39. Elsevier BV. http://dx.doi. org/10.1016/j.jchromb.2017.04.048.
22. Yuan Y, Macquarrie D. Microwave-assisted extraction of sulfated polysaccharides (fucoidan) from Ascophyllum nodosum and its antioxidant activity. Carbohydrate Polymers [S.L.] 2015;129:101-107. Elsevier BV. http:// dx.doi.org/10.1016/j.carbpol.2015.04.057.

23. Yuan Y, et al. Microwave-assisted hydrothermal extraction of polysaccharides from Ulva prolifera: functional properties and bioactivities. Carbohydrate Polymers [S.L.] 2018;181: 902-910, fev. 2018. Elsevier BV. http://dx.doi.org/10.1016/j.carbpol.2017.11.061.

24. PrajapatiVD, etal.Retracted:Carrageenan.Carbohydrate Polymers [S.L.] 2014;105:97-112. Elsevier BV. http:// dx.doi.org/10.1016/j.carbpol.2014.01.067.

25. Pereira L. Population studies and Carrageenan properties in eight gigartinales (Rhodophyta) from western coast of Portugal. The Scientific World Journal [S.L.] 2013:1-11. Hindawi Limited. http://dx.doi. org/10.1155/2013/939830. 